\title{
REVIEW
}

\section{Year in review 2009: Critical Care - infection}

\author{
Stephan Harbarth* and Thomas Haustein
}

\begin{abstract}
In 2009 Critical Care provided important and clinically relevant research data for management and prevention of infections in critically ill patients. The present review summarises the results of these observational studies and clinical trials and discusses them in the context of the current relevant scientific and clinical background. In particular, we discuss recent epidemiologic data on nosocomial infections in intensive care units, present new approaches to prevention of ventilatorassociated pneumonia, describe recent advances in biomarker-guided antibiotic stewardship and attempt to briefly summarise specific challenges related to the management of infections caused by multidrugresistant microorganisms and influenza $\mathrm{A}(\mathrm{H} 1 \mathrm{~N} 1)$.
\end{abstract}

\section{Introduction}

The year 2009 was again an interesting one for readers interested in the field of infection in critically ill patients. Several promising new approaches for the prevention of infections in the intensive care unit (ICU) setting were presented. Furthermore, progress was noted in the difficult area of antimicrobial stewardship and risk stratification of infected patients. Finally, several challenges related to influenza infections and the management of difficult-to-treat infections were tackled or better delineated [1]. The present short review will summarise the results of a selection of original studies, with a special focus on articles published in Critical Care in 2009.

\section{Epidemiology of infection in critically ill patients}

New insights were reported regarding the epidemiology of infection in ICUs. A global, observational study (EPIC II) on the prevalence and outcomes of infection in 1,265 ICUs was conducted in 75 countries in May 2007. Among the 13,796 patients, 9,084 (66\%) patients received an antimicrobial agent and 7,087 (51\%) patients were

${ }^{*}$ Correspondence: stephan.harbarth@hcuge.ch

Infection Control Program, Geneva University Hospitals and Medical School, 4 rue G-P-G, CH-1211 Geneva 14, Switzerland considered infected at the time of data collection [2]. Unfortunately, owing to methodological limitations, no clear-cut distinction could be made between communityassociated and healthcare-associated infections. Among those patients who had stayed longer than 7 days in the ICU prior to the study day, however, more than $70 \%$ were infected, mostly with multidrug-resistant organisms (MDROs). A clear association was noted between prevalence of infection and hospital mortality, with Greece and Turkey having the highest mortality and Switzerland the lowest [2].

Since this type of prevalence study does not allow one to draw any strong causal inferences between infection rates and excess mortality due to ICU-acquired infections, longitudinal cohort studies with more sophisticated analyses have to be conducted. For instance, a recent French ICU-based case-control study matched 1,725 deceased patients with 1,725 surviving control patients to determine the excess mortality related to ICU-acquired infection [3]. The adjusted population-attributable fraction of deaths due to ICU-acquired infection for patients who died before their ICU discharge was 14.6\% (95\% confidence interval $(\mathrm{CI})=14.4$ to 14.8 ). The attributable mortality of ventilator-associated pneumonia (VAP) was $6.1 \%(95 \% \mathrm{CI}=5.7$ to 6.5$)$, an estimate close to the $8.1 \%$ ( $95 \% \mathrm{CI}=3.1$ to $13.1 \%$ ) provided by a multistate model of another cohort study that appropriately handled VAP as a time-dependent event [4].

VAP is a serious complication after major heart surgery in many parts of the world; however, its prevalence and epidemiology varies considerably from hospital to hospital $[5,6]$. In a recent pan-European cohort study conducted in 25 hospitals in eight different European countries, one or more nosocomial infections were detected in 43 (4.4\%) patients. VAP was the most frequent nosocomial infection (2.1\%; 13.9 episodes per 1,000 days of mechanical ventilation) [6]. Overall, this rate of VAP is relatively high compared with other surveillance data [7] and warrants further preventive efforts, as described below.

\section{Prevention of ventilator-associated pneumonia}

In many ICUs there is an urgent need to improve adherence to already established infection control measures designed to minimise the risk and rates of VAP. Technology-driven, costly or risky approaches such as 
coated endotracheal tubes or selective digestive decontamination should not be implemented as standard of care for all patients $[8,9]$. Instead, high priority should be given to improving routine hand hygiene, as well as to other routine preventive measures such as backrest elevation $>30^{\circ}$, correct cuff-pressure maintenance, avoidance of gastric overdistension and nonessential tracheal suction, and good oral hygiene, which is probably one of the most important and easy-to-perform interventions to successfully prevent VAP [10].

The use of chlorhexidine-based oral rinses could be particularly helpful in preventing endogenous and exogenous contamination of patients' upper and lower airways by decreasing the bacterial load present in the oropharyngeal flora [11]. Scannapieco and colleagues conducted a randomised, double-blind, placebocontrolled clinical trial of chlorhexidine gluconate on oral bacterial pathogens in mechanically ventilated patients [12]. While 175 subjects were randomised, full follow-up assessment after at least 48 hours of ICU stay was only available for 115 patients. Chlorhexidine reduced the number of Staphylococcus aureus, but not the total number of Enterobacteriacae, Pseudomonas spp. or Acinetobacter spp. in the dental plaque of included subjects. A nonsignificant reduction in VAP rates was noted in groups treated with chlorhexidine compared with the placebo group (odds ratio $=0.54,95 \% \mathrm{CI}=0.23$ to 1.25). A similar study conducted in Spain investigating the effectiveness of oral rinses with chlorhexidine in preventing nosocomial respiratory tract infections among ICU patients also failed to demonstrate a significant effect [13]. It remains to be elucidated whether the limited power or other methodological issues related to these studies could explain the negative study results $[14,15]$.

\section{Chlorhexidine-based infection control measures}

Several recently published high-quality studies have highlighted the potential benefit of using chlorhexidine for the prevention of catheter-related bloodstream infections. A prospective randomised trial was performed in seven ICUs of five French hospitals to assess the effect of two preventive practices on catheter-related bloodstream infection rates: frequency of dressing change (3 days vs. 7 days) and type of dressing (standard vs. chlorhexidine-impregnated sponges) [16]. The use of chlorhexidine-impregnated sponges decreased the rate of catheter-related bloodstream infection from an already low level of 1.3 to 0.4 episodes per 1,000 catheter-days without an increase in chlorhexidine-resistant microorganisms. Changing catheter dressings every 7 days was not inferior to changing dressings every 3 days in terms of rate of colonisation [16]. Two studies conducted in the USA suggested that routine chlorhexidine body washes may also help to reduce catheter-related bloodstream infection rates in different settings $[17,18]$.

Chlorhexidine body washes have now become the standard of care in many ICUs to reduce the bacterial load on patients' skin. A British team of investigators examined the impact of several control interventions aimed at reducing cross-transmission of methicillinresistant S. aureus [19]. An educational campaign and cohorting had little impact on methicillin-resistant S. aureus transmission. The introduction of chlorhexidine as a skin antiseptic reduced methicillin-resistant S. aureus transmission of all but one of the strains prevalent in this ICU: the TW strain that carries the $q a c A / B$ genes that code for chlorhexidine resistance [19]. Owing to its chlorhexidine resistance, the acquisition of this methicillin-resistant $S$. aureus strain increased dramatically during the period of this interrupted timeseries study. The emergence of resistance has also been observed with other topical decontamination regimens; it is therefore important to actively look for emerging chlorhexidine resistance in settings with widespread chlorhexidine usage [20].

\section{Management of severe and difficult-to-treat infections}

Treatment of VAP caused by MDROs has been limited by the poor diffusion of certain intravenous antibiotics (for example, aminoglycosides) into the alveolar compartment of the lungs. An elegant solution to this challenge could consist of the aerosolisation of antibiotic agents with special methods and devices [21]. In a recent pilot study, French investigators showed that a new mode of delivery of aerosolised amikacin achieved very high drug concentrations in the lung, while maintaining safe serum levels in 28 mechanically ventilated patients with Gramnegative VAP treated for 7 to 14 days, adjunctive to intravenous therapy [22]. Despite these recent promising findings, the widespread use of aerosolised antibiotics to treat VAP cannot be recommended at present and should be restricted to the treatment of multidrug-resistant Gram-negative VAP, as pointed out by the same group of investigators in a recent review [21].

The management of postoperative peritonitis caused by MDROs may also represent a clinical challenge [23,24]. Augustin and colleagues determined risk factors for the presence of MDROs in postoperative peritonitis in 100 patients, as well as optimal empirical antibiotic therapy choices among different, commonly suggested treatment options [25]. Adequate empirical therapy was achieved in only $64 \%$ of cases. Adequacy decreased significantly in patients with MDROs, as compared with patients presenting other bacteria (39\% vs. $81 \%, P<0.0001)$. However, as also observed in another recent article on staphylococcal bacteremia [26], mortality in the study by 
Augustin and colleagues did not differ between patients who received adequate empiric therapy and those who did not (30\% vs. 31\%), or between patients with peritonitis caused by MDROs and other bacteria ( $29 \%$ for MDRO group vs. $35 \%$ for others). Importantly, the definition of adequacy in this study was based purely on microbiological criteria and did not take yeasts into account. The single antibiotics providing the best activity rate were imipenem/cilastatin and piperacillin/tazobactam. The best adequacy for empiric therapy was obtained by combinations of imipenem/cilastatin or piperacillin/tazobactam, amikacin and a glycopeptide [25]. This finding is in line with two recent studies from 2010 on the use of antibiotic combinations. Both studies recommend antibiotic combination therapy over monotherapy for the initial empiric treatment phase of the most severely ill patients with septic shock $[27,28]$.

Antifungal therapy has been revolutionised within the past 10 years. New treatment options and indications have continuously entered critical care and have increased the competition and marketing pressure. In this overheated area of medicine with continuous influx of new products and industry-sponsored clinical studies [29], it remains rather difficult for the nonexpert critical care physician to evaluate true progress and the effectiveness of different antifungal agents in daily clinical practice, including the toxicity profile of older agents [30].

Marriott and colleagues [31] undertook a nationwide prospective clinical and microbiological cohort study of all episodes of ICU-acquired candidaemia occurring in non-neutropenic adults in Australian ICUs between 2001 and 2004 [32]. Overall, 183 patients had ICU-acquired candidaemia with a 30 -day case-fatality rate of $56 \%$. Host factors (older age, mechanical ventilation and ICU admission diagnosis) and failure to receive systemic antifungal therapy were significantly associated with mortality on multivariate analysis. Process of care measures advocated in recent guidelines were implemented inconsistently: follow-up blood cultures were obtained in $68 \%$ of patients, central venous catheters were removed within 5 days in $80 \%$ of patients and ophthalmological examination was performed in $36 \%$ of patients. This study showed that crude mortality remains high in Australian ICU patients with candidaemia. Among those who were treated, mortality was overwhelmingly related to host factors but not treatment variables (the time to initiation of antifungals or fluconazole pharmacokinetic and pharmacodynamic factors) [31].

Zilberberg and colleagues investigated the costeffectiveness of a new echinocandin antifungal agent (micafungin) as an alternative to fluconazole in the empirical treatment of suspected ICU-acquired candidaemia among septic patients in a simulation model [33].
In the base case analysis, the authors assumed a high attributable mortality of ICU-acquired candidaemia $(40 \%)$ and an overly optimistic risk reduction $(52 \%)$ in mortality with appropriate timely therapy. Of note, in the Australian cohort study cited above, antifungal therapy was commonly started among treated patients $>48$ hours after drawing the first positive blood culture; this delay was not associated with increased mortality [31]. Moreover, the model assumptions were mainly based on the North-American epidemiology of azole-resistant Candida spp. infections. Compared with fluconazole (total deaths 31), treatment with micafungin (total deaths 27) would result in four fewer deaths at an incremental cost per death averted of $\$ 61,446$, leading to an incremental cost-effectiveness of the echinocandin over fluconazole of $\$ 34,734$ (95\% CI $=\$ 26,312$ to $\$ 49,209)$ per quality-adjusted life year.

This cost-effectiveness analysis has severe limitations, since the methodology used is deficient both in terms of the modelling strategy as well as the reliability of the probability estimates. The authors used an oversimplified approach and, sometimes, questionable probability estimates, resulting in biasing their analysis in favour of the intervention (providing empiric anti-Candida therapy) and in favour of micafungin versus fluconazole. Although empiric micafungin may well be an attractive treatment strategy, the deficiencies in this analysis preclude its widespread use. This study therefore should only represent the starting point for further investigations of the cost-effectiveness of different treatment strategies of suspected and confirmed fungal infections in the critical care setting.

\section{Antibiotic stewardship and risk prediction}

At the current time, procalcitonin (PCT) represents the best studied biomarker for guiding antibiotic treatment duration in the hospital setting $[34,35]$. Several highquality clinical trials investigating the diagnostic performance and clinical effectiveness of PCT have been published within the past 3 years [36-39]. Two large-scale studies confirmed the potential usefulness of PCT to guide antibiotic use in critically ill patients $[37,39]$. Nevertheless, in the study by Bouadma and colleagues more than one-half $(53 \%)$ of patients enrolled in the PCT-guided arm did not follow the protocol for initial antibiotic treatment decisions - and thus antimicrobial use was not completely determined by PCT levels, as recommended [39]. PCT in critically ill patients therefore probably remains a suboptimal marker to strongly influence initial treatment decisions or even to withhold empiric therapy for potentially life-threatening infections. PCT measurements may, however, increase the confidence of clinicians to withdraw antimicrobial therapy at an earlier timepoint in the majority of patients. 
Table 1. Comparison of community-acquired pneumonia risk scores for the prediction of intensive care unit treatment

\begin{tabular}{|c|c|c|c|c|}
\hline & REA-ICU index ${ }^{a}$ & SMART-COPb & IDSA/ATS prediction rule ${ }^{c}$ & SCAPd $^{d}$ \\
\hline Outcome & $\begin{array}{l}\text { ICU transfer within } 3 \text { days } \\
\text { of hospital admission }\end{array}$ & $\begin{array}{l}\text { Need for intensive respiratory } \\
\text { or vasopressor support }\end{array}$ & ICU admission & $\begin{array}{l}\text { Mechanical ventilation, } \\
\text { septic shock, or } \\
\text { in-hospital death }\end{array}$ \\
\hline Study inclusion criteria & $\begin{array}{l}\text { Adult patients with CAP } \\
\text { without respiratory failure } \\
\text { or shock at the time of } \\
\text { hospitalisation }\end{array}$ & $\begin{array}{l}\text { Adult patients hospitalised } \\
\text { with CAP }\end{array}$ & $\begin{array}{l}\text { Patients aged }>15 \text { years } \\
\text { hospitalised for }>12 \text { hours } \\
\text { with CAP }\end{array}$ & $\begin{array}{l}\text { Adult patients with CAP } \\
\text { visiting the emergency } \\
\text { department (including } \\
\text { patients with expected } \\
\text { terminal event) }\end{array}$ \\
\hline Study exclusion criteria & Nursing home residents & $\begin{array}{l}\text { Hospitalisation within the } \\
\text { preceding } 14 \text { days, } \\
\text { immunosuppression, receipt } \\
\text { of parenteral antibiotics prior } \\
\text { to obtainment of blood } \\
\text { samples for culture, aspiration } \\
\text { pneumonitis, withdrawal of } \\
\text { active treatment within } \\
12 \text { hours because of a poor } \\
\text { prognosis, pregnancy }\end{array}$ & Immunosuppression & Immunosuppression \\
\hline Number of criteria & 11 & 8 & 11 (2 major, 9 minor) & 8 (2 major, 6 minor) \\
\hline \multicolumn{5}{|l|}{ Variable underlying the criteria } \\
\hline Respiratory rate & $\bullet$ & $\bullet$ & $\bullet$ & $\bullet$ \\
\hline Heart rate & $\bullet$ & $\bullet$ & & \\
\hline Systolic blood pressure & & $\bullet$ & $\bullet$ & $\bullet$ \\
\hline $\begin{array}{l}\text { Septic shock with need } \\
\text { for vasopressors }\end{array}$ & & & $\bullet$ & \\
\hline Body temperature & & & $\bullet$ & \\
\hline $\begin{array}{l}\text { Confusion/altered } \\
\text { mental status }\end{array}$ & & $\bullet$ & $\bullet$ & $\bullet$ \\
\hline $\begin{array}{l}\text { Invasive mechanical } \\
\text { ventilation }\end{array}$ & & & $\bullet^{e}$ & \\
\hline Multilobar infiltrate & $\bullet$ & $\bullet$ & $\bullet$ & $\bullet$ \\
\hline Oxygenation & $\bullet$ & $\bullet$ & $\bullet$ & - \\
\hline Arterial pH & $\bullet$ & $\bullet$ & & $\bullet$ \\
\hline Blood urea nitrogen & $\bullet$ & & $\bullet$ & $\bullet$ \\
\hline Albumin level & & - & & \\
\hline Sodium & $\bullet$ & & & \\
\hline White blood cell count & $\bullet$ & & $\bullet$ & \\
\hline Platelet count & & & $\bullet$ & \\
\hline Age & $\bullet$ & & & $\bullet$ \\
\hline Gender & $\bullet$ & & & \\
\hline Co-morbid conditions & $\bullet$ & & & \\
\hline Sensitivity & $14 \%(10 \text { to } 19)^{9}$ & $92 \%(85 \text { to } 97)^{9}$ & $71 \%(66 \text { to } 76)^{f}$ & $92 \% 9$ \\
\hline Specificity & $97 \%(96 \text { to } 97)^{9}$ & $62 \%(59 \text { to } 66)^{9}$ & $88 \%(87 \text { to } 88)^{f}$ & $74 \%^{9}$ \\
\hline $\begin{array}{l}\text { Area under ROC curve in } \\
\text { derivation cohort }\end{array}$ & $0.81(0.78 \text { to } 0.83)^{9}$ & $0.87(0.83 \text { to } 0.91)^{9}$ & Not reported & $0.83^{9}$ \\
\hline
\end{tabular}

CAP, community-acquired pneumonia; ICU, intensive care unit; ROC, receiver operating characteristic. a Renaud and colleagues [PMID 19358736] [46]. ${ }^{\mathrm{b}} \mathrm{Charles}$ and colleagues [PMID 18558884] [44]. 'Liapikou and colleagues [PMID 19140759] [45]. 'España and colleagues [PMID 16973986] [43]. eMajor criterion. 'Values apply to validation cohort. ${ }^{9}$ Values apply to derivation cohort.

To further clarify the kinetics of PCT within the first days of sepsis in relation to adequacy of antibiotic therapy, Charles and colleagues conducted an observational cohort study in 180 septic patients [40]. Appropriate initial antibiotic therapy was associated with a significantly greater decrease in PCT until day 3. The 
baseline PCT level failed to predict outcome, but on day 3 higher PCT levels were measured in the nonsurvivors when compared with the survivors. This is the first study to demonstrate that the PCT dynamics within 72 hours after onset of sepsis may be correlated both with appropriateness of the empirical antibiotic therapy and with overall survival. Whether this interesting observation can be incorporated into clinical management guidelines needs to be further evaluated.

Another marker of inflammation, C-reactive protein remains widely used throughout the world for diagnosis of infectious conditions - despite its rather limited diagnostic accuracy when used as a single measurement in time [41]. Paran and colleagues therefore investigated the dynamic nature of $\mathrm{C}$-reactive protein in a cohort of patients admitted to an emergency department in Israel [42]. They constructed a new index, C-reactive protein velocity, which was defined as the ratio of $\mathrm{C}$-reactive protein on admission to the number of hours since the onset of fever. The C-reactive protein velocity improved differentiation between febrile bacterial infections and nonbacterial febrile illnesses compared with $\mathrm{C}$-reactive protein alone. If confirmed by other groups, this approach could provide clinicians with a valuable tool for establishing the correct diagnosis and better identifying individuals who need prompt therapeutic interventions [42].

\section{Community-acquired pneumonia risk stratification}

The severity of community-acquired pneumonia may be difficult to judge clinically. As a consequence, multiple scores have been proposed with the aim of predicting the risk of adverse outcomes in critically ill patients [43-45]. None of the existing rules is ideal; weaknesses include low sensitivity or specificity, excessive complexity, underestimation of severity in younger patients, and poor prediction of ICU admission.

In view of both the high cost and potential benefit of critical care, there is a need for tools that help ensure timely ICU admission for all patients with pneumonia for whom this is likely to improve outcome. The REA-ICU index developed by Renaud and colleagues aims to preemptively identify patients at risk of requiring secondary transfer to ICU within the first 3 days of their hospital admission [46]. The prediction rule was derived from a cohort of 4,593 patients initially presenting without overt circulatory or respiratory failure and was based on 11 criteria. Nursing home residents were excluded. The highest risk class was assigned to $3.6 \%$ of evaluated patients; among this group, the rate of ICU transfer within 3 days of admission was around 30\%.

Do we need yet another community-acquired pneumonia severity score? The merit of the study by Renaud and colleagues is its focus on patients who are at high risk despite not being obvious ICU candidates on admission.
The REA-ICU index may not, however, constitute a major advance in the overall endeavour of identifying those patients who will or should benefit from critical care [47]. Compared with existing prediction rules, the REA-ICU index is neither less complex nor does it appear to be clearly superior in guiding patient management (Table 1). A head-to-head validation of the existing scores in a prospective study with separation of evaluators and clinical decision-makers would be desirable to better judge their utility in clinical practice.

\section{H1N1 influenza A}

The influenza A (H1N1) pandemic was certainly the most featured infectious disease in 2009. Several highly accessed contributions were published in Critical Care during this year. Rello and Pop-Vicas highlighted the clinical challenges associated with primary influenza pneumonia [48]. Influenza A (H1N1) illness severity and the case-fatality rate were described in an interesting case series of 32 relatively young patients (median, 36 years) hospitalised in Spain between 23 June and 31 July 2009 [49]. Twenty-four patients (75\%) developed multiorgan dysfunction, and eight patients died. As confirmed by later cohort studies from Australia and the UK [50,51], pulmonary complications of influenza A (H1N1) infection in pregnant and young obese but previously healthy persons were associated with adverse health outcomes. The same Spanish group investigated the host immune response following infection with influenza A (H1N1) [52]. Interestingly, severe $\mathrm{H} 1 \mathrm{~N} 1$ disease with respiratory involvement was characterised by early secretion of specific cytokines usually associated with cell-mediated immunity but also commonly linked to the pathogenesis of inflammatory diseases.

\section{Conclusions}

Infection remains one of the key challenges of critical care and significantly contributes to morbidity and mortality. Papers published in recent months remind us that further reductions of nosocomial infection rates are possible - often with the help of simple interventions. Antimicrobial resistance is a permanent threat for ICU patients and there is growing awareness that available antimicrobial agents should be used wisely. Biomarkers of infection can help to make more appropriate treatment decisions. The rapid proliferation of published research data entails a need for consolidation of existing knowledge as exemplified by the growing number of community-acquired pneumonia severity scores. Clearly, infections in the ICU continue to be an exciting and important topic for ongoing research.

\section{Abbreviations}

$\mathrm{Cl}$, confidence interval; ICU, intensive care unit; $\mathrm{MDRO}$, multidrug-resistant microorganism; PCT, procalcitonin; VAP, ventilator-associated pneumonia. 


\section{Competing interests}

$\mathrm{SH}$ received consultant and speaker honoraria from BioMerieux, DaVolterra and DestinyPharma. TH declares that he has no competing interests.

\section{Acknowledgements}

Work by the authors was supported by the European Community, 6th Framework Programme (MOSAR network contract LSHP-CT-2007-037941 and CHAMP network contract SP5A-CT-2007-044317)

Published: 5 November 2010

\section{References}

1. Schechner V, Nobre V, Kaye KS, Leshno M, Giladi M, Rohner P, Harbarth S, Anderson DJ, Karchmer AW, Schwaber MJ, Carmeli Y: Gram-negative bacteremia upon hospital admission: when should Pseudomonas aeruginosa be suspected? Clin Infect Dis 2009, 48:580-586.

2. Vincent JL, Rello J, Marshall J, Silva E, Anzueto A, Martin CD, Moreno R, Lipman J, Gomersall C, Sakr Y, Reinhart K: International study of the prevalence and outcomes of infection in intensive care units. JAMA 2009, 302:2323-2329.

3. Januel JM, Harbarth S, Allard R, Voirin N, Lepape A, Allaouchiche B, Guerin C, Lehot JJ, Robert MO, Fournier G, Jacques D, Chassard D, Gueugniaud PY, Artru F, Petit P, Robert D, Mohammedi I, Girard R, Cêtre JC, Nicolle MC, Grando J, Fabry J, Vanhems P: Estimating attributable mortality due to nosocomial infections acquired in intensive care units. Infect Control Hosp Epidemiol 2010, 31:388-394

4. Nguile-Makao M, Zahar JR, Francais A, Tabah A, Garrouste-Orgeas M, Allaouchiche B, Goldgran-Toledano D, Azoulay E, Adrie C, Jamali S, Clec'h C, Souweine B, Timsit JF: Attributable mortality of ventilator-associated pneumonia: respective impact of main characteristics at ICU admission and VAP onset using conditional logistic regression and multi-state models. Intensive Care Med 2010, 36:781-789.

5. Hortal J, Giannella M, Perez MJ, Barrio JM, Desco M, Bouza E, Munoz P. Incidence and risk factors for ventilator-associated pneumonia after major heart surgery. Intensive Care Med 2009, 35:1518-1525.

6. Hortal J, Munoz P, Cuerpo G, Litvan H, Rosseel PM, Bouza E: Ventilatorassociated pneumonia in patients undergoing major heart surgery: an incidence study in Europe. Crit Care 2009, 13:R80.

7. Gastmeier P, Geffers C, Brandt C, Zuschneid I, Sohr D, Schwab F, Behnke M, Daschner $\mathrm{F}$, Ruden $\mathrm{H}$ : Effectiveness of a nationwide nosocomial infection surveillance system for reducing nosocomial infections. J Hosp Infect 2006, 64:16-22.

8. Afessa B, Shorr AF, Anzueto AR, Craven DE, Schinner R, Kollef MH: Association between a silver-coated endotracheal tube and reduced mortality in patients with ventilator-associated pneumonia. Chest 2010, 137:1015-1021.

9. Oostdijk EA, de Smet AM, Blok HE, Thieme Groen ES, van Asselt GJ, Benus RF, Bernards SA, Frenay $I H$, Jansz AR, de Jongh BM, Kaan JA, Leverstein-van Hall MA, Mascini EM, Pauw W, Sturm PD, Thijsen SF, Kluytmans JA, Bonten MJ: Ecological effects of selective decontamination on resistant Gramnegative bacterial colonization. Am J Respir Crit Care Med 2010, 181:452-457.

10. Bouadma L, Mourvillier B, Deiler V, Le Corre B, Lolom I, Regnier B, Wolff M, Lucet JC: A multifaceted program to prevent ventilator-associated pneumonia: impact on compliance with preventive measures. Crit Care Med 2010, 38:789-796

11. Segers P, Speekenbrink RG, Ubbink DT, van Ogtrop ML, de Mol BA: Prevention of nosocomial infection in cardiac surgery by decontamination of the nasopharynx and oropharynx with chlorhexidine gluconate: a randomized controlled trial. JAMA 2006, 296:2460-2466

12. Scannapieco FA, Yu J, Raghavendran K, Vacanti A, Owens SI, Wood K, Mylotte JM: A randomized trial of chlorhexidine gluconate on oral bacterial pathogens in mechanically ventilated patients. Crit Care 2009, 13:R117.

13. Bellissimo-Rodrigues F, Bellissimo-Rodrigues WT, Viana JM, Teixeira GC, Nicolini E, Auxiliadora-Martins M, Passos AD, Martinez EZ, Basile-Filho A, Martinez R: Effectiveness of oral rinse with chlorhexidine in preventing nosocomial respiratory tract infections among intensive care unit patients. Infect Control Hosp Epidemiol 2009, 30:952-958.

14. Michaud S, Suzuki S, Harbarth S: Effect of design-related bias in studies of diagnostic tests for ventilator-associated pneumonia. Am J Respir Crit Care Med 2002, 166:1320-1325.

15. Fourrier F, Dubois D, Pronnier P, Herbeca P, Leroy O, Desmettre T, Pottier-Cau E, Boutigny H, Di Pompeo C, Durocher A, Roussel-Delvallez M: Effect of gingival and dental plaque antiseptic decontamination on nosocomial infections acquired in the intensive care unit: a double-blind placebocontrolled multicenter study. Crit Care Med 2005, 33:1728-1735.

16. Timsit JF, Schwebel C, Bouadma L, Geffroy A, Garrouste-Orgeas M, Pease S, Herault MC, Haouache H, Calvino-Gunther S, Gestin B, Armand-Lefevre L, Leflon V, Chaplain C, Benali A, Francais A, Adrie C, Zahar JR, Thuong M, Arrault X, Croize J, Lucet JC; Dressing Study Group: Chlorhexidine-impregnated sponges and less frequent dressing changes for prevention of catheterrelated infections in critically ill adults: a randomized controlled trial. JAMA 2009, 301:1231-1241

17. Popovich KJ, Hota B, Hayes R, Weinstein RA, Hayden MK: Effectiveness of routine patient cleansing with chlorhexidine gluconate for infection prevention in the medical intensive care unit. Infect Control Hosp Epidemiol 2009, 30:959-963.

18. Munoz-Price LS, Hota B, Stemer A, Weinstein RA: Prevention of bloodstream infections by use of daily chlorhexidine baths for patients at a long-term acute care hospital. Infect Control Hosp Epidemiol 2009, 30:1031-1035.

19. Batra R, Cooper BS, Whiteley C, Patel AK, Wyncoll D, Edgeworth JD: Efficacy and limitation of a chlorhexidine-based decolonization strategy in preventing transmission of methicillin-resistant Staphylococcus aureus in an intensive care unit. Clin Infect Dis 2010, 50:210-217.

20. Kluytmans J, Harbarth S: Methicillin-resistant Staphylococcus aureus decolonization:'yes, we can,' but will it help? Infect Control Hosp Epidemiol 2009, 30:633-635

21. Luyt CE, Combes A, Nieszkowska A, Trouillet JL, Chastre J: Aerosolized antibiotics to treat ventilator-associated pneumonia. Curr Opin Infect Dis 2009, 22:154-158.

22. Luyt CE, Clavel M, Guntupalli K, Johannigman J, Kennedy Jl, Wood C, Corkery K, Gribben D, Chastre J: Pharmacokinetics and lung delivery of PDDSaerosolized amikacin (NKTR-061) in intubated and mechanically ventilated patients with nosocomial pneumonia. Crit Care 2009, 13:R200

23. Montravers P, Gauzit R, Muller C, Marmuse JP, Fichelle A, Desmonts JM: Emergence of antibiotic-resistant bacteria in cases of peritonitis after intraabdominal surgery affects the efficacy of empirical antimicrobial therapy. Clin Infect Dis 1996, 23:486-494.

24. Harbarth S, Uckay l: Are there patients with peritonitis who require empiric therapy for enterococcus? Eur J Clin Microbiol Infect Dis 2004, 23:73-77.

25. Augustin P, Kermarrec N, Muller-Serieys C, Lasocki S, Chosidow D, Marmuse JP, Valin N, Desmonts JM, Montravers P: Risk factors for multidrug resistant bacteria and optimization of empirical antibiotic therapy in postoperative peritonitis. Crit Care 2010, 14:R20.

26. Ammerlaan $H$, Seifert $H$, Harbarth S, Brun-Buisson C, Torres A, Antonelli M, Kluytmans J, Bonten M: Adequacy of antimicrobial treatment and outcome of Staphylococcus aureus bacteremia in 9 Western European countries. Clin Infect Dis 2009, 49:997-1005.

27. Kumar A, Zarychanski R, Light B, Parrillo J, Maki D, Simon D, Laporta D, Lapinsky S, Ellis P, Mirzanejad Y, Martinka G, Keenan S, Wood G, Arabi Y, Feinstein D, Kumar A, Dodek P, Kravetsky L, Doucette S; Cooperative Antimicrobial Therapy of Septic Shock (CATSS) Database Research Group: Early combination antibiotic therapy yields improved survival compared with monotherapy in septic shock: a propensity-matched analysis. Crit Care Med 2010, 38:1773-1785.

28. Micek ST, Welch EC, Khan J, Pervez M, Doherty JA, Reichley RM, Kollef MH: Empiric combination antibiotic therapy is associated with improved outcome against sepsis due to Gram-negative bacteria: a retrospective analysis. Antimicrob Agents Chemother 2010, 54:1742-1748.

29. Kullberg BJ, Sobel JD, Ruhnke M, Pappas PG, Viscoli C, Rex JH, Cleary JD, Rubinstein E, Church LW, Brown JM, Schlamm HT, Oborska IT, Hilton F, Hodges MR: Voriconazole versus a regimen of amphotericin B followed by fluconazole for candidaemia in non-neutropenic patients: a randomised non-inferiority trial. Lancet 2005, 366:1435-1442.

30. Harbarth S, Pestotnik SL, Lloyd JF, Burke JP, Samore MH: The epidemiology of nephrotoxicity associated with conventional amphotericin B therapy. Am J Med 2001, 111:528-534

31. Marriott DJ, Playford EG, Chen S, Slavin M, Nguyen Q, Ellis D, Sorrell TC: Determinants of mortality in non-neutropenic ICU patients with candidaemia. Crit Care 2009, 13:R115.

32. Chen S, Slavin M, Nguyen Q, Marriott D, Playford EG, Ellis D, Sorrell T: Active surveillance for candidemia, Australia. Emerg Infect Dis 2006, 12:1508-1516.

33. Zilberberg MD, Kothari S, Shorr AF: Cost-effectiveness of micafungin as an alternative to fluconazole empiric treatment of suspected ICU-acquired candidemia among patients with sepsis: a model simulation. Crit Care 
2009, 13:R94

34. Harbarth S, Albrich WC, Muller B: When once is not enough - further evidence of procalcitonin-guided antibiotic stewardship. Crit Care 2009, 13:165.

35. Schuetz P, Albrich W, Christ-Crain M, Chastre J, Mueller B: Procalcitonin for guidance of antibiotic therapy. Expert Rev Anti Infect Ther 2010, 8:575-587.

36. Nobre V, Harbarth S, Graf JD, Rohner P, Pugin J: Use of procalcitonin to shorten antibiotic treatment duration in septic patients: a randomized trial. Am J Respir Crit Care Med 2008, 177:498-505.

37. Schuetz P, Christ-Crain M, Thomann R, Falconnier C, Wolbers M, Widmer I, Neidert S, Fricker T, Blum C, Schild U, Regez K, Schoenenberger R, Henzen C, Bregenzer T, Hoess C, Krause M, Bucher HC, Zimmerli W, Mueller B; ProHOSP Study Group: Effect of procalcitonin-based guidelines vs standard guidelines on antibiotic use in lower respiratory tract infections: the ProHOSP randomized controlled trial. JAMA 2009, 302:1059-1066.

38. Stolz D, Smyrnios N, Eggimann P, Pargger H, Thakkar N, Siegemund M, Marsch S, Azzola A, Rakic J, Mueller B, Tamm M: Procalcitonin for reduced antibiotic exposure in ventilator-associated pneumonia: a randomised study. Eur Respir J 2009, 34:1364-1375.

39. Bouadma L, Luyt CE, Tubach F, Cracco C, Alvarez A, Schwebel C, Schortgen F, Lasocki S, Veber B, Dehoux M, Bernard M, Pasquet B, Régnier B, Brun-Buisson C, Chastre J, Wolff M; PRORATA trial group: Use of procalcitonin to reduce patients' exposure to antibiotics in intensive care units (PRORATA trial): a multicentre randomised controlled trial. Lancet 2010, 375:463-474.

40. Charles PE, Tinel C, Barbar S, Aho S, Prin S, Doise JM, Olsson NO, Blettery B, Quenot JP: Procalcitonin kinetics within the first days of sepsis: relationship with the appropriateness of antibiotic therapy and the outcome. Crit Care 2009, 13:R38.

41. Christ-Crain M, Morgenthaler NG, Stolz D, Muller C, Bingisser R, Harbarth S, Tamm M, Struck J, Bergmann A, Muller B: Pro-adrenomedullin to predict severity and outcome in community-acquired pneumonia [ISRCTN04176397]. Crit Care 2006, 10:R96.

42. Paran Y, Yablecovitch D, Choshen G, Zeitlin I, Rogowski O, Ben-Ami R, Katzir M, Saranga H, Rosenzweig T, Justo D, Orbach Y, Halpern P, Berliner S: C-reactive protein velocity to distinguish febrile bacterial infections from nonbacterial febrile illnesses in the emergency department. Crit Care 2009, 13:R50.

43. España PP, Capelastegui A, Gorordo I, Esteban C, Oribe M, Ortega M, Bilbao A, Quintana JM: Development and validation of a clinical prediction rule for severe community-acquired pneumonia. Am J Respir Crit Care Med 2006, 174:1249-1256.

44. Charles PG, Wolfe R, Whitby M, Fine MJ, Fuller AJ, Stirling R, Wright AA, Ramirez JA, Christiansen KJ, Waterer GW, Pierce RJ, Armstrong JG, Korman TM,
Holmes P, Obrosky DS, Peyrani P, Johnson B, Hooy M; Australian CommunityAcquired Pneumonia Study Collaboration, Grayson ML: SMART-COP: a tool for predicting the need for intensive respiratory or vasopressor support in community-acquired pneumonia. Clin Infect Dis 2008, 47:375-384.

45. Liapikou A, Ferrer M, Polverino E, Balasso V, Esperatti M, Piner R, Mensa J, Luque N, Ewig S, Menendez R, Niederman MS, Torres A: Severe communityacquired pneumonia: validation of the Infectious Diseases Society of America/American Thoracic Society guidelines to predict an intensive care unit admission. Clin Infect Dis 2009, 48:377-385.

46. Renaud B, Labarere J, Coma E, Santin A, Hayon J, Gurgui M, Camus N, Roupie E. Hemery F, Herve J, Salloum M, Fine MJ, Brun-Buisson C: Risk stratification of early admission to the intensive care unit of patients with no major criteria of severe community-acquired pneumonia: development of an international prediction rule. Crit Care 2009, 13:R54.

47. Chalmers JD: ICU admission and severity assessment in communityacquired pneumonia. Crit Care 2009, 13:156.

48. Rello J, Pop-Vicas A: Clinical review: primary influenza viral pneumonia. Crit Care 2009, 13:235.

49. Rello J, Rodriguez A, Ibanez P, Socias L, Cebrian J, Marques A, Guerrero J, Ruiz-Santana S, Marquez E, Del Nogal-Saez F, Alvarez-Lerma F, Martínez S, Ferrer M, Avellanas M, Granada R, Maraví-Poma E, Albert P, Sierra R, Vidaur L, Ortiz P, Prieto del Portillo I, Galván B, León-Gil C; H1N1 SEMICYUC Working Group: Intensive care adult patients with severe respiratory failure caused by Influenza A (H1N1)v in Spain. Crit Care 2009, 13:R148.

50. Bishop JF, Murnane MP, Owen R: Australia's winter with the 2009 pandemic influenza A (H1N1) virus. N Engl J Med 2009, 361:2591-2594.

51. Yeung JH, Bailey M, Perkins GD, Smith FG: Presentation and management of critically ill patients with influenza A (H1N1): a UK perspective [letter]. Crit Care 2009, 13:426.

52. Bermejo-Martin JF, Ortiz de Lejarazu R, Pumarola T, Rello J, Almansa R, Ramirez P, Martin-Loeches I, Varillas D, Gallegos MC, Seron C, Micheloud D, Gomez JM, Tenorio-Abreu A, Ramos MJ, Molina ML, Huidobro S, Sanchez E, Gordón M, Fernández V, Del Castillo A, Marcos MA, Villanueva B, López CJ, RodríguezDomínguez M, Galan JC, Cantón R, Lietor A, Rojo S, Eiros JM, Hinojosa C, et al:: Th1 and Th17 hypercytokinemia as early host response signature in severe pandemic influenza. Crit Care 2009, 13:R201.

doi:10.1186/cc9268

Cite this article as: Harbarth S, Haustein T: Year in review 2009: Critical Care infection. Critical Care 2010, 14:240. 